From a draft. May differ from the published version, which appeared in Monism: Science, Philosophy, Religion, and the History of a Worldview, ed. Todd Weir, 135-158, New York: Palgrave USA, 2012.

\title{
Monism and Morphology at the Turn of the Twentieth Century
}

\author{
SANDER GLIBOFF
}

Indiana University

\begin{abstract}
Ernst Haeckel's monistic worldview and his interpretation of Darwin's theory of evolution worked together to help him rule out any role for divine providence or any non-material mind, spirit, will, or purpose in the organic world. In his account of 1866, the impersonal, unpredictable, and purposeless external environment was what drove evolutionary change.

By around the turn of the twentieth century, however, new theories of evolution, heredity, and embryology were challenging Haeckel's, but Haeckel no longer responded with his earlier vigor. Younger monistically oriented evolutionary biologists had to take the lead in modernizing and defending the monistic interpretation and the external causes of evolution. Three of these younger biologists are discussed here: Haeckel's student, the morphologist-turned-theoretician Richard Semon (1859-1918); Ludwig Plate (1862-1937), who took over Haeckel's chair at the University of Jena and became an influential journal editor and commentator on new research on heredity and evolution; and Paul Kammerer (1880-1926), whose experimental evidence for the modifying power of the environment was hotly debated.

Despite their very different social, political, and religious backgrounds, their contrasting research methods and career trajectories, and their disagreements on the precise mechanisms of evolution, these three were united by their adherence to Haeckelian monistic principles. Together they illustrate the continuing importance of Haeckel's biological and ideological program in the twentieth century, its ability to adapt to new theoretical and methodological challenges, and its successful defense of the purposelessness of Darwinian variation and the non-directedness of evolution.
\end{abstract}

Keywords: Evolution, Monism, Morphology, Ernst Haeckel, Ludwig Plate, Richard Semon, Paul Kammerer, Germany, Austria, Early $20^{\text {th }}$ Century.

\section{Introduction}

As Todd Weir observes in his Introduction, the monism of Ernst Haeckel (18341919) was "a naturalistic worldview based chiefly on the theory of biological 
evolution." ${ }^{1}$ But what, exactly, was "the" theory of biological evolution, according to Haeckel? And to what extent might the reverse have been true and the theory have depended on the worldview? For the foundations of monism demanded more from evolution than the mere transformation of species, and not all of the competing theories of Haeckel's day could satisfy those demands equally well. In fact, Haeckel rejected some of them quite vehemently for their incompatibility with monism.

Some theories were obviously "dualistic," in that they posited transcendental plans and purposes to guide evolution or dictate form, and so were unusable. Others had to be rejected because they allowed the mind and the perceived needs of the organism to cause and direct evolutionary change. But Haeckel also rejected some accounts that were ostensibly mechanistic and materialistic in character and intention, but violated his monistic strictures in subtler ways. In short, the requirements of his monism informed and constrained Haeckel's theory preferences and helped him narrow down the field. What he presented in the end as the theory of biological evolution was an interpretation of Darwin's work, carefully crafted not only for its biological and practical merits, but also for enforcing monistic principles.

The connection between the theory and the worldview was not lost on Haeckel's critics, who often disparaged the former in order to undermine the latter. In the long run, the 1916 Form and Function, by biologist E. S. Russell has been most damaging. Russell wrote that Haeckel "combined his evolutionism and his materialism to form a queer Monism of his own," and that Haeckel was "too trenchantly materialistic, too much the populariser of a crude and commonplace philosophy of Nature" to represent mainstream morphology. Haeckel's system, moreover, was naïvely reductionistic, with "the form and activities of living things... held to be merely the mechanical result of the physical and chemical composition of their bodies." Somewhat contradictorily, he also described Haeckel as believing in transcendental archetypes that guided development, as Goethe and the Romantic Naturphilosophen imagined it. ${ }^{2}$

By other accounts, the trouble with Haeckel's monism was not its materialism, but its mysticism and mushy-headedness. As the early historian of biology Erik Nordenskiöld complained, Haeckel "entertains," on the one hand, "a blind faith in the power of 'mechanical causality' to explain anything whatever," but

1. Todd Weir, ed., Monism: Science, Philosophy, Religion, and the History of a Worldview (New York: Palgrave USA, 2012), ch. 1.

2. E. S. Russell, Form and Function: A Contribution to the History of Animal Morphology (London: John Murray, 1916), 248, 250 \& 260. 
on the other hand, keeps attributing mental and spiritual qualities to matter and indulges in "pantheistic reveries" and "romantic idealism." 3

These contrasting caricatures of Haeckel's monism have both been surprisingly influential and have been used for decades to dismiss Haeckel's biological theory choices and interpretations as shallow, ideological, unscientific, and even immoral. Jürgen Sandmann, for example, played the materialism card in order to claim that Haeckel supported a mechanistic and deterministic model of behavior that rendered humanitarian ethics impossible. Stephen J. Gould relied heavily on Russell's and Nordenskiöld's authority to paint Haeckel's theories anew as excessively deterministic. In addition, he condemned Haeckel's brand of "biological determinism" by association with twentieth-century racism, Nazism, and other ideologies. ${ }^{4}$ Other recent authors take a slightly softer line, granting that Haeckel at least thought he was embracing Darwinian notions of historical contingency, but painting him as intellectually inconsistent and still connecting him to romanticism, types, and rigid developmental pathways. ${ }^{5}$ There are, however, some moves being made toward a reevaluation of Haeckel in relation to both Darwin and pre-Darwinian German morphology. ${ }^{6}$

3. Erik Nordenskiöld, The History of Biology: A Survey, trans. Leonard Bucknall Eyre (1928; repr., New York: Tudor Publishing, 1936), 513 \& 515.

4. Jürgen Sandmann, Der Bruch mit der humanitären Tradition: Die Biologisierung der Ethik bei Ernst Haeckel und anderen Darwinisten seiner Zeit (Stuttgart and New York: Gustav Fischer, 1990); Stephen J. Gould, Ontogeny and Phylogeny (Cambridge, MA: Belknap Press of Harvard University Press, 1977); for a more extensive critique of this literature, see also Robert J. Richards, The Tragic Sense of Life: Ernst Haeckel and the Struggle Over Evolutionary Thought (Chicago and London: University of Chicago Press, 2008), 4-6.

5. E.g.,Olaf Breidbach, "The Former Synthesis: Some Remarks on the Typological Background of Haeckel's Ideas About Evolution," Theory in Biosciences 121 (2002): 280-296; Olaf Breidbach, "The Conceptual Framework of Evolutionary Morphology in the Studies of Ernst Haeckel and Fritz Müller," Theory in Biosciences 124 (2006): 265-280; Mario A. Di Gregorio, From Here to Eternity: Ernst Haeckel and Scientific Faith (Göttingen: Vandenhoeck \& Ruprecht, 2005).

6. E.g., Richards, The Tragic Sense of Life; Sander Gliboff, H. G. Bronn, Ernst Haeckel, and the Origins of German Darwinism: A Study in Translation and Transformation (Cambridge, MA: MIT Press, 2008); Peter J. Bowler, review of H. G. Bronn, Ernst Haeckel, and the Origins of German Darwinism, by Sander Gliboff, Isis 100 (2009): 671-672. 
If these accounts of Haeckel's determinism and materialism were correct, then why would Haeckel reject - as he sometimes did with great vehemencecertain mechanistic accounts of evolution that invoked the physical sciences as their methodological model, and even sought deterministic laws of development and evolution? And by the same token, if he were as much of a pantheist or panpsychist as Nordenskiöld claimed, why would he also reject any suggestion that organic matter might be endowed with will and purpose, and be able to guide its own evolution?

In this paper, I will consider briefly the influence of monism on Haeckel's account of biological evolution, why this account both precluded the determinism so often attributed to him and strictly limited the psychical attributes of organic matter. Then I will investigate what became of Haeckel's monistic strictures on evolution in the early twentieth century. For it seems to me that in the long run, Haeckel was more successful in drawing and defending the line demarcating monistic and naturalistic theories from dualistic, vitalistic, and theistic ones than he was in establishing his particular theory.

Haeckel's Darwinism served him well, as both a research program and a foundation for monism, from the 1860s through the 1890s. But as the turn of the twentieth century approached, Haeckel's hypothetical mechanisms of variation, heredity, and evolution were getting long in the tooth, and Haeckel himself failed to appreciate how rapidly the field was abandoning them. He underestimated the importance of Mendelian genetics and experimental approaches to embryology, as well as the threats to his program from new versions of neo-Darwinism, Lamarckism, saltationism, orthogenesis, and theistic evolution. But younger biologists in Germany and Austria took up the task of keeping evolutionary theory in line with monism. They responded to Haeckel's critics, used Haeckel's principles to identify and reject what was incompatible with monism, and they tried to modernize Haeckel's interpretation of Darwinism as the theory of biological evolution.

Three of those younger biologists will be treated here: Richard Semon (18591918), Ludwig Plate (1862-1937), and Paul Kammerer (1880-1926). They came from different social and religious backgrounds, were far apart politically, and even differed in their scientific goals and assumptions and in their personal opinions of Haeckel, but they were united by a common commitment to monistic evolution in Haeckel's sense. Together, these three illustrate the viability and diversity of the monistic school of evolutionary and morphological thought, and its continuing strength in the twentieth century. Indeed, I would even like to suggest that traces of their reasoning (and Haeckel's) can even be detected in the evolutionary synthesis of the 1930s and 1940s, as well as in later evolutionary thought, particularly when it comes to demarcating natural 
and mechanistic theories from vitalistic and theistic ones.

\section{Monism and Mechanism in Haeckel's Evolutionary Morphology}

In the system that Haeckel introduced in his magnum opus, Generelle Morphologie [General Morphology] of 1866, evolutionary change was always triggered and directed by the environment - the unpredictable, mindless, and aimless environment. Environmental stimuli made the organism vary the course of its development in one way or another. The changes could be "direct," if the organism immediately acquired new morphological or physiological characteristics, or new habits (which in turn could generate further variation). They could also be "indirect," if the changes were strictly internal and became manifest only in the next generation. ${ }^{7}$

Assuming they were adaptive - and Haeckel often wrote as if most variation would indeed be adaptive - then such responses of the organism to the environment would be preserved by natural selection and could somehow be impressed upon the very material that made up the developing individual. They would, in a sense, be recalled, and the developmental responses repeated, when part of the same organic material found itself in descendants of a modified individual. ${ }^{8}$ This was the basis for what Haeckel later called the "biogenetic law," the principle that ontogeny recapitulated phylogeny: present-day embryos were re-enacting, in part, the changes that its ancestors had gone through. ${ }^{9}$ The idea was of immense importance for Haeckel's practical program of reconstructing evolutionary history, based on embryological evidence.

For philosophical and rhetorical purposes, however, the important point was the agency of the external environment in initiating change. If mindless

and impersonal things like food supply or climate were sufficient as drivers of

7. Ernst Haeckel, Generelle Morphologie der Organismen: Allgemeine Grundzüge der organischen Formen-Wissenschaft, mechanisch begründet durch die von Charles Darwin reformierte Descendenz-Theorie, 2 vols. (Berlin: Georg Reimer, 1866), 2:191-202; For more detailed discussion, see also Gliboff, Origins of German Darwinism, ch. 5.

8. Haeckel developed the memory analogy later in an essay that would be inspirational for Semon: Ernst Haeckel, Die Perigenesis der Plastidule: Oder die Wellenzeugung der Lebenstheilchen: Ein Versuch zur mechanischen Erklärung der elementaren Entwickelungs-Vorgänge (Berlin: Georg Reimer, 1876).

9. Haeckel, Generelle Morphologie, 1: 151-152. 
evolution, then divine providence and any non-corporeal mind, spirit, goal, or need was superfluous.

Haeckel rejected alternative theories of evolution that did not make proper use of external causes of change, even if they were otherwise entirely mechanistic. Such theories evoked the preformationism of the eighteenth century, which held that every individual developed from a germ that had been present in its parent, the parental germ in the parent's parent, and so on. Each germ developed mechanically when its time came, but it was strongly implied that the germs had been designed and put into place at the Creation, and that the system did not so much respond to environmental changes and historical contingencies as anticipate them.

Evolutionary change was possible under such theories, since there was no strict requirement for a daughter-germ or -egg to be identical to that of its parent. With divine foreknowledge, an apparently evolutionary sequence could have been arranged, which could even have been synchronized with environmental changes. It amounted to a biological version of the Leibnizian "prästabilisierte Harmonie" [prestabilized harmony] between the inner and outer worlds, which kept the two in synchrony without requiring them to interact. Life, although changing over time, would not participate meaningfully in any truly historical process. ${ }^{10}$

Haeckel saw the same implications in some of the most mechanistic nineteenthcentury systems, for example that of embryologist Wilhelm His (1831-1904). His argued, in essence, that mechanical forces such as those generated by the cells of the embryo, as they divided, grew, and pushed against one another, were what shaped the organism. All the biologist had to know were the initial configuration of material in the fertilized egg and the laws of embryonic mechanics, and, in principle, he could calculate how the adult would turn out. By extension, the same laws and forces shaped the reproductive organs, eggs, the next generation, and, indeed, the whole lineage. Environment, history, and hereditary impressions or material had little to do with it. ${ }^{11}$

From Haeckel's point of view, His's developmental sequence was just like

10. Phillip R. Sloan, "Buffon, German Biology, and the Historical Interpretation of Biological Species," British Journal for the History of Science 12 (1979): 109-153.

11. E.g., Wilhelm His, Unsere Körperform und das physiologische Problem ihrer Entstehung (Leipzig: F. C. W. Vogel, 1874). In later works he admitted a greater role for the environment, but not in the 1870s when he was attacking Haeckel. 
the preformationist's sequence of germs, because it ran a predetermined course from the Creation on, unbroken and uninfluenced by interaction with the environment. There was no apparent reason why the sequences should just happen to produce adaptive variations when needed. Both would therefore seem to require divine foreknowledge of the environments the organisms would encounter.

The traditional alternative to preformation was "epigenetics," the idea that forms were produced anew in each generation, and that the generative process could be shaped by circumstances, and Haeckel's polemics against His frequently alluded to those two antagonistic views. Haeckel continually contrasted his dual mechanisms of conservative heredity and progressive and creative adaptation with His's supposed revival of preformation:

Phylogeny is the mechanical cause of ontogeny....With this statement an unbridgeable chasm is defined, which separates the older, teleological and dualistic morphology from the newer, mechanistic and monistic one. If the physiological functions of heredity and adaptation are shown to the sole causes of organic form, then therewith, at the same time, every source of teleology, of dualistic and metaphysical points of view, will be removed from the field of biogeny. The sharp opposition between the two guiding principles is thus clearly defined. Either a direct, causal connection between ontogeny and phylogeny exists or it does not exist. Either Ontogeny is a condensed excerpt of phylogeny or it is not. Between these two assumptions there is no third one! Either epigenesis and descent or preformation and Creation! [Emphasis original.] ${ }^{12}$

Haeckel thus drew a clear line from His to preformation to divine Creation, while associating himself with monism, mechanism, and the epigeneticist opposition to preformationism.

\section{New Challenges and Champions of Monism in the Twentieth Century}

Haeckel's fierce defenses notwithstanding, his monistic system of morphology was vulnerable to attack on several fronts. One tempting target was the optimistic slant of Haeckel's rhetoric about adaptation and progress, and his characteristic usage of the terms "adaptation," "progressive heredity" and

12. Ernst Haeckel, "Die Gastraea-Theorie, die phylogenetische Classification des Thierreichs und die Homologie der Keimblätter," Jenaische Zeitschrift für Naturwissenschaft 8 [= NF 1] (1874): 6-9. 
"variation" as if they were all interchangeable, and all variation would be adaptive and progressive.

In his more detailed treatments, and in his later works, Haeckel did discuss unfavorable variations and non-progressive evolution, and made it clear he knew they were common, but he was not much interested in them. Unfavorable variations were of no practical importance for the reconstruction of phylogeny, because one did not see them recorded in heredity and being recapitulated in the embryo. Natural selection eliminated them. But if Haeckel could be construed as believing that variation really was always or mostly favorable, his system could be turned on its head. It could be made into a teleological account of evolution, in which the organism responded actively and purposefully to the environment, instead of being buffeted this way and that. That was, in fact, one of the counter-arguments used by the theistic evolutionist Erich Wasmann in 1907, which Plate took the lead in rebutting.

Other vulnerable points were methodological, especially after embryology took its experimental turn in the 1890s. The school of Entwicklungsmechanik, or developmental mechanics, shifted the focus of embryology away from the reconstruction of evolutionary history on the basis of comparative study, and toward the elucidation of the internal workings of the embryo, using experimentation. It seriously doubted that ontogeny was shaped more by phylogenetic history than by internal mechanisms. Haeckel never warmed to these new approaches to embryology, and he underestimated the extent to which they would come to dominate the field. He claimed that experimental methods would not reveal anything of value about heredity and variation that was not already apparent to the comparatists and to practical breeders. ${ }^{13}$

Still other weaknesses were exposed by progress in the study of heredity. August Weismann's neo-Darwinism and germplasm theory of the 1880s and 1890s had already attempted to sequester the hereditary material and isolate it from the very kinds of environmental influences that Haeckel relied upon for generating variation. Even though it was entirely hypothetical, the level of structural and mechanical detail that Weismann provided set a high standard and called attention to the lack of specifics from Haeckel about how variation was generated and remembered by the protoplasm. These problems became even more pressing after 1900, with the "rediscovery" of Mendel and the first

13. Ernst Haeckel, "Zur Phylogenie der australischen Fauna: Systematische Einleitung," introduction to Zoologische Forschungsreisen in Australien und dem malayischen Archipel: Mit Unterstützung des Herrn Dr. Paul von Ritter, ausgeführt in den Jahren 1891-1893, by Richard Semon (Jena: Gustav Fischer, 1893), iv. 
attempts to ascribe a material basis to Mendelian factors and to locate them on the chromosomes. Haeckel's monistic mechanisms looked awfully vague in comparison. But, as was the case with Entwicklungsmechanik, Haeckel did not think these approaches were worthy rivals to his own. He considsered Mendelism just another theory of hereditary particles, like Weismann's determinants or Darwin's gemmules, which had no great advantage over his own memory analogy. ${ }^{14}$

\section{Ludwig Plate}

Although he had been introduced to evolutionary biology as a student attending Haeckel's lectures in Jena, and later benefitted from Haeckel's support when he was called to Jena in 1909, Ludwig Plate fought bitterly with Haeckel as soon as they came into close contact. Plate took over Haeckel's chair of Zoology and the Phyletic Museum that Haeckel had founded, and resented Haeckel's continuing interest in and presence at the museum. He treated Haeckel with disdain, accused him of misappropriating funds, and partially repudiated his previous support of Haeckel's monism. ${ }^{15}$

14. Ernst Haeckel, "Darwin as an Anthropologist," in Darwin and Modern Science: Essays in Commemoration of the Centenary of the Birth of Charles Darwin and of the Fiftieth Anniversary of the Publication of the "Origin of Species," ed. A. C. Seward (Cambridge: Cambridge University Press, 1909); Ernst Haeckel, Natürliche Schöpfungs-Geschichte: Gemeinverständliche wissenschaftliche Vorträge über die Entwicklungslehre im allgemeinen und diejenige von Darwin, Goethe und Lamarck im besonderen, 11 ${ }^{\text {th }}$ ed. (Berlin: Georg Reimer, 1911); Georg Uschmann, "Ernst Haeckel und der Mendelismus," Folia Mendeliana Musei Moraviae Brno 6 (1971): 311-318.

15. On Plate's career and relationship to Haeckel and to modern Darwinism, see also: Georgy S. Levit and Uwe Hoßfeld, "The Forgotten 'Old-Darwinian' Synthesis: The Evolutionary Theory of Ludwig H. Plate (1862-1937)," NTM: Internationale Zeitschrift für Geschichte und Ethik der Naturwissenschaften, Technik und Medizin 14 (2006): 9-25; Gloria Robinson, "Plate, Ludwig Hermann," in Dictionary of Scientific Biography, ed. Charles C. Gillispie (New York: Charles Scribner's Sons, 1975); Heinz Penzlin, ed., Geschichte der Zoologie in Jena nach Haeckel (1909-1974) (Jena and Stuttgart: Gustav Fischer, 1994). 
Plate has been described as a "notorious bully, Pan-Germanist, and racist."16 In politics, Plate was indeed far to the Right, and he supported the National Socialist Party, even before it came to power, but apparently was not a party member. ${ }^{17}$ The shift in his stance on monism after his arrival in Jena can perhaps be attributed to his increasing political engagement.

By the 1920s Plate was connecting Haeckel's monism very strongly with leftist and Jewish interests: "The Jews and the Social Democrats celebrate Haeckel as their great prophet, because, through his atheism and materialism, he smoothed the way for their corrosive endeavors, and, in a way, justified them scientifically." 18

Plate distanced himself from what he saw as the atheism and anti-religious politics of monism, but not necessarily from the scientific agenda. Other monists might be leftist, philo-Semitic, and cosmopolitan, he argued, but: "I, on the other hand, am an idealist, a freethinking Christian, nationalistically German [deutsch-völkisch], and an anti-Semite." 19 He continued to consider himself a monist, but emphasized a unity of nature that could include aspects of the divine and need not entirely exclude his Christian and Germanic identity.

My interest here is in the role Plate played in defending and modernizing Haeckel's interpretation of evolutionary theory, and keeping it in line with monistic expectations, especially where the environmental causes of variation were concerned.

\section{Plate on Orthogenesis and Psycho-lamarckism}

Plate made his debut as critical analyst of trends in evolution and heredity with an 1899 lecture on natural selection before the German Zoological Society. The text of the lecture went through several incarnations as an article and grew into an oft-revised book, whose title varied somewhat. ${ }^{20}$ The repeated revisions,

16. Richard Goldschmidt, Portraits from Memory: Recollections of a Zoologist (Seattle: University of Washington Press, 1956), 38.

17. Levit and Hoßfeld, 13.

18. Statement of June 24, 1921, quoted inHeinrich Schmidt, Ernst Haeckel und sein Nachfolger: Professor Dr. Ludwig Plate (Jena: Volksbuchhandlung, 1921), 19.

19. From a magazine article in the Deutsch-völkische Monatshefte, 1921, no. 1, p. 33, as quoted in ibid., 19.

20. E.g., Ludwig Plate, Über die Bedeutung des Darwin'schen Selectionsprinzips und Probleme der Artbildung, $2^{\text {nd }}$ ed. (Leipzig: Wilhelm Engelmann, 
along with Plate's editorializing in the Archiv für Rassen- und GesellschaftsBiologie [Archive for Racial- and Social Biology], show how a Haeckelian monist passed judgment on the latest developments in heredity and evolutionary theory.

In matters of heredity, Plate acknowledged and valued the achievements of Mendelian genetics, but refused to jump to the conclusion that all heredity was Mendelian and all hereditary material chromosomal. His theorizing always left room for the production of new variation by environmental effects, in the Haeckelian manner, but also for special storage systems for the important unifying characteristics of the major phylogenetic groups. ${ }^{21}$

In evolutionary theory, Plate was less flexible than on questions of heredity. He came out strongly in opposition to orthogenesis, any inner drive toward perfection, or any modifying mechanism that was blind to environmental change. He called such systems teleological, vitalistic or mystical, and pointed out that they were also superfluous. Any number of other theories, from Theodor Eimer's application of environmental effects, to natural selection, to Weismann's germinal selection, could account for evolutionary trends just as well. Plate had no patience with paleontologists who arranged their fossil specimens into neat, progressive lines and presented them as evidence of directional forces within the organism. When paleontologist Otto Jaeckel did just that in 1902, Plate responded severely and condescendingly and reduced him to sputtering about his years of experience with fossils and Plate's lack of respect. ${ }^{22}$ Plate

1903); Ludwig Plate, Selektionsprinzip und Probleme der Artbildung: Ein Handbuch des Darwinismus, $4^{\text {th }}$ ed. (Leipzig and Berlin: Wilhelm Engelmann, 1913). He later supplemented the book with a shorter, popularizing account:Ludwig Plate, Die Abstammungslehre: Tatsachen, Theorien, Einwände und Folgerungen in kurzer Darstellung, $2^{\text {nd }}$ ed. (Jena: Gustav Fischer, 1925).

21 . His views on heredity are expounded in the various editions of his selection book, see previous note, as well as in the book on heredity that he later spun off from it: Ludwig Plate, Vererbungslehre: Mit besonderer Berücksichtigung des Menschen, für Studierende, Ärzte und Züchter, 2 vols. (Jena: Gustav Fischer, 1913); Ludwig Plate, Vererbungslehre: Mit besonderer Berücksichtigung der Abstammungslehre und des Menschen, 3 vols., $2^{\text {nd }}$ ed. (Jena: Gustav Fischer, 1932-1938). For further details on his system of heredity, see Levit and Hoßfeld.

22. Ludwig Plate, "Ueber O. Jaekel's Schrift betreffend die verschiedenen Wege phylogenetischer Entwicklung," Naturwissenschaftliche Wochenschrift 18 [= NF 2] (1902): 101-3; Otto Jaekel, "Erwiderung auf Herrn Plate's Kritik meines Aufsatzes über Descendenz," Naturwissenschaftliche Wochenschrift 18 
continued to make an example of him in later editions of his book. ${ }^{23}$

Another group of victims were the psycho-Lamarckians, led by August Pauly, a professor of forestry in Munich. They tried to argue that the animal psyche played an active role in recognizing and assessing its needs and initiating the appropriate morphological change and adaptation. ${ }^{24}$ Plate answered them in good Haeckelian style, banishing them to the fringes of scientific respectability for making the psyche an agent of evolutionary change. The psyche had to be a product of evolution, according to the monistic view, and so could not be its cause. $^{25}$

\section{Wasmann in Berlin, 1907}

In his high-profile books and public lectures on evolution and religion, Erich Wasmann stood out among all the critics of monism for his impressive credentials as both a naturalist and a theologian. ${ }^{26} \mathrm{He}$ did pathbreaking work on the morphology, behavior, and even the evolution of ants and their commensals, but he was also a Jesuit priest, who was perceived to speak for the Catholic church. ${ }^{27} \mathrm{He}$ went a long way with the evolutionists, giving evolutionary interpretations of life in ant- and termite colonies, and allowing that natural selection played at least some role in the evolutionary process. In his rebuttals to Haeckel and the monists, he did not have to resort only to arguments about

[= NF 2] (1902): 234-235.

23. Plate, Selektionsprinzip und Probleme der Artbildung, $502 \& 512$.

24. August Pauly, Darwinismus und Lamarckismus: Entwurf einer psychophysischen Teleologie (Munich: Ernst Reinhardt, 1905); Oskar Prochnow, "Mein Psychovitalismus," Archiv für Rassen- und Gesellschafts-Biologie 6 (1909): 232236.

25. Ludwig Plate, "Gegen den Psychovitalismus: Nachwort zu dem vorstehenden Aufsatze von O. Prochnow: 'Mein Psychovitalismus,'" Archiv für Rassen- und Gesellschafts-Biologie 6 (1909): 237-239.

26. E.g., Robert J. Richards, "Ernst Haeckel and the Struggles Over Evolution and Religion," Annals of the History and Philosophy of Biology 10 (2005): 100-102; Heike Barantzke, "Erich Wasmann (29.5.1859-27.2.1931): Jesuit und Zoologe in Personalunion," Jahrbuch für Geschichte und Theorie der Biologie 6 (1999): $77-140$.

27. His accommodation of evolution actually got him into trouble with his superiors, but that was not generally known at the time: Barantzke. 
general principles of monism or theology - the nature of matter, eternity, and the like - but also discussed the mechanisms of evolution in great detail.

In a 1907 series of public lectures in Berlin, ${ }^{28}$ which, he insisted repeatedly, was not intended to recall Haeckel's lectures at the very same venue two years previously, ${ }^{29}$ Wasmann homed in on the issue of internal and external causes of variation. He fully appreciated its ideological ramifications, and he realized that Haeckelian monists had to limit the effects of inner laws and causes, because of their potential for being interpreted teleologically. So he tried to show that the monists could not actually do so, because purposeful responsiveness was implicit in the monists' own notion of an environmentally induced variation:

Let us now go somewhat further into the inner developmental laws of the organic world. On this, we will be answered by the monist side, that we do not need such "inexplicable inner developmental laws!" But if one goes just so far as to assume the responsiveness [Reaktionsfähigkeit] of living substance to external stimuli, then one immediately faces a thoroughgoing purposiveness [Zweckm $\ddot{a}$ ßigkeit] that cannot be explained away, and that is simply because the teleology [Zielstrebigkeit] is already in there. But I must say, frankly: The inner developmental laws are in there, too! [Emphasis original. $]^{30}$

Thus, according to Wasmann, environmental forces alone could not reshape the organism. The organism's living substance had an active role to play as well.

28. I rely on the account compiled and edited by Plate: Ludwig Plate, ed., Ultramontane Weltanschauung und moderne Lebenskunde, Orthodoxie und Monismus: Die Anschauungen des Jesuitenpaters Erich Wasmann und die gegen ihn in Berlin gehaltenen Reden (Jena: Gustav Fischer, 1907); for a more sympathetic reading of Wasmann seeAbigail Lustig, "Erich Wasmann, Ernst Haeckel and the Limits of Science," Theory in Biosciences 121 (2002): 252-259.

29. Ernst Haeckel, Der Kampf um den Entwicklungsgedanken: Drei Vorträge, gehalten am 14., 16. und 19. April 1905 im Saale der Sing-Akademie zu Berlin (Berlin: Georg Reimer, 1905); in English: Ernst Haeckel, Last Words on Evolution: A Popular Retrospect and Summary, trans. Joseph McCabe (London: A. Owen, 1906).

30. Erich Wasmann, "Theistische und atheistische Entwicklungslehre: Darwinismus und Entwicklungslehre," II. Vortrag des P. Wasmann, am 14. Februar im Oberlichtsaal der Berliner Philharmonie, in Plate, Ultramontane Weltanschauung, 31-32. 
It had to respond to the environment, and the response had to be purposeful if it were to produce favorable variations.

At the same time, Wasmann had to protect himself against being characterized as a preformationist, even if he did believe an internal developmental process had been set into motion at the Creation. He therefore offered a compromise in which internal and external causes of change interacted. One could not account for evolution just by studying the laws of growth and embryology:

It would be completely backwards to construe the inner developmental laws, which the Christian world view assumes to be the main and fundamental principle of the evolution of the organic word, as an already fully wound-up clockwork that only has to run down. A "pre-stabilized harmony" between organism and environment is also not to be assumed; no, the interaction, the tendency toward interaction, is the thing that allows the inner and the outer developmental factors to work together. ${ }^{31}$

Wasmann then drove home the point that Darwinism, as interpreted by Haeckel and the monists, was not a valid alternative. Implicitly, he argued, it was already assuming inner, teleological processes in its account of variation:

That which is called the irritability [Reizbarkeit] of protoplasm, the capacity to respond to external stimuli, that is identical to the inner developmental laws. These laws are steered into certain pathways by external influences and fixed through heredity. By this process, there originate ever more specialized developmental directions that rest, most fundamentally, on the same internal basis from which they started out. [Emphasis original.] ${ }^{32}$

He gave the Haeckelians no credit for allowing any complex interplay between the internal and the external, but portrayed their interpretation of Darwin as purely and unjustifiably externalistic: "Therefore, the inner developmental laws are not to be denied, as has often been done by the Darwinian side before and as is still being done." 33 He placed the burden on the Darwinians to show that they could take internal causes into account and allow them to generate favorable variations, yet not allow them to be purposeful.

31. Ibid., 32.

32. Ibid., 32.

33. Ibid., 32. 


\section{Plate's Monistic Response}

In response, Plate refused to let Wasmann pose as a Darwinian evolutionist (no matter how critical a one) and an anti-Darwinian at the same time. The very idea of an "immanent teleology" that, as Wasmann would have it, made sure that "the changes that occurred under new conditions always turned out to be on the purposive side" 34 was inherently vitalistic. It was not only incompatible with the monistic interpretation of Darwinism, but also, Plate argued, plainly false on empirical grounds.

In contrast to Haeckel's earlier optimistic rhetoric about the progressive and adaptive nature of variation - which Wasmann was turning against him and making into an argument for teleology-Plate now made it crystal clear that organisms generally were not capable of responding constructively to environmental conditions for which they were not already adapted:

What if we bring an organism into quite new and unusual conditions, under which neither it nor its ancestors had ever found themselves before? What does it do then, if the conditions are harmful? Does it always act in a way that turns out to be beneficial? Does it always, or at least for quite the most part, react purposively, or does it react extraordinarily often in a purposeless way? Now you all know that the organism, under quite new conditions, reacts almost regularly, alas, alas, in a purposeless way. ${ }^{35}$

In other words, it gets sick or even dies.

In a footnote, Plate gave many examples of organisms failing to deal adequately with environmental challenges, dying of the exposure instead of being modified by it. But, he stressed, the important thing was that no matter how organisms responded to the environment, their response was dictated by the laws of chemistry and physics. Neither the organisms nor any hypothetical purposive principle in them could possibly have any choice in the matter.

Well, then, how could purposeful adaptations result from such a purposeless, deterministic system? The key was in variation. History gave every individual a unique constitution, because each was a product of a unique sequence of environmental effects on uniquely constituted ancestors. Whenever enough variation was generated, some of the variants would just happen to be favorable, and this would not require any special explanation:

34. Ludwig Plate, "Rede des Herrn Prof. Plate," in Plate, Ultramontane Weltanschauung, 64.

35. Ibid., 65. 
The answer can only be given in the sense of Darwin: in times of need, the individuals of a species never react all in the same way. Some go one way, some go another, because they are always somewhat different in their inner constitutions. Therefore, the ones who chance to change themselves in a purposeful way are preserved and transmit their good characteristics through heredity. ${ }^{36}$

\section{Richard Semon}

Richard Semon was Haeckel's most devoted student and follower. He admired Haeckel personally and embraced his approach to monism and to science. His greatest debts to Haeckel, he once recalled, were the practical lessons in how to think and to do research monistically, always viewing humanity as part of nature, and all branches of human knowledge as interconnected. ${ }^{37}$ In politics, Semon was a liberal nationalist, in religion a converted Jew. He appears to have converted not out of any great religious conviction, but more as an expression of his German national and cultural identification. ${ }^{38}$

As a young biologist, Semon dreamed of exploring the tropics and collecting exotic animals there, but he caught malaria in Africa on his first voyage and barely made it back to Europe alive. Years later, with financial backing orchestrated by Haeckel, he traveled to Australia with much greater success. The result was a landmark work on the embryology and morphology of the Australian fauna, which took twenty years and a large number of collaborators to complete. ${ }^{39}$

36. Ibid., $67 \mathrm{n}$.

37. Richard Semon, "Aus Haeckels Schule," in Was wir Ernst Haeckel verdanken: Ein Buch der Verehrung und Dankbarkeit, ed. Heinrich Schmidt (Leipzig: Unesma, 1914).

38. For biographical information, I rely on Daniel L. Schacter, Stranger Behind the Engram: Theories of Memory and the Psychology of Science (Hillsdale, NJ: Lawrence Erlbaum, 1982); Jürg Schatzmann, Richard Semon (1859-1918) und seine Mnemetheorie (Zürich: Juris-Verlag, 1968); Paul Kammerer, "Richard Semon: Zur Wiederkehr seines Todestages," Der Abend (Vienna), Dec. 27, 1920, from a photocopy in the Kammerer Papers, APS Library, Philadelphia.

39. Richard Semon, Zoologische Forschungsreisen in Australien und dem malayischen Archipel: Mit Unterstützung des Herrn Dr. Paul von Ritter, ausgeführt in den Jahren 1891-1893, 6 vols. (Jena: Gustav Fischer, 1893-1913). 
For years Semon was content to work on morphological problems within the intellectual and methodological framework that Haeckel provided, but his work took a theoretical turn after the turn of the twentieth century. He saw the new experimental embryology of the 1890s and the Mendelism of the early 1900s as challenges to his comparative work and to Haeckel's monistic interpretation of Darwinism, and developed his Mneme theory of organic memory in response.

Semon's Mneme book of 1904 supplied crucial details, missing from Haeckel's older accounts, of just how environmental effects were supposed to be stored in heredity and recalled and reenacted during development. Semon's dedication to the Haeckelian program was evident throughout the book. His concept of organic memory was strictly monistic in the sense that no conscious mind or non-material spirit was involved. Protoplasm had the purely physical property of being able to store environmental effects as "engrams" and to "ekphorize" them at appropriate times in development. ${ }^{40}$ The second edition, from 1908 added a response to the Mendelians and a case for the Mneme-theory as an alternative explanation of hybridization experiments. ${ }^{41}$

Like Haeckel, Semon provided a balance between the dual mechanisms of heredity and variation. Variation, as before, was caused by external forces impinging on the organism and forcing changes in its development. And heredity was understood in a new way, but still as a form of organic memory. Because heredity still stored and replayed ancestral responses to the environment, Semon's theory strengthened Haeckel's rationale for reconstructing phylogeny from embryological evidence. ${ }^{42}$ It also advanced Haeckel's monistic goal of unifying mental and physical processes.

Semon's theory underscored the uniqueness of every individual. Not only did every individual experience and respond to the environment in its own way, but its protoplasm also carried a unique complement of stored memories of its ancestors' experiences of and responses to the environment. Here we see Semon lending support to Plate's claim, contra Wasmann, that every individual had a unique constitution and would therefore respond uniquely to an environmental stimulus. The unique constitution was a product of historical events, as "remembered" by the protoplasm. ${ }^{43}$

40. Richard Semon, Die Mneme als erhaltendes Prinzip im Wechsel des organischen Geschehens (Leipzig: Wilhelm Engelmann, 1904).

41. Richard Semon, Die Mneme als erhaltendes Prinzip im Wechsel des organischen Geschehens, $2^{\text {nd }}$ ed. (Leipzig: Wilhelm Engelmann, 1908).

42. Ibid., $22 \& 383-384$.

43. Ibid., 229-253. 
The principle of individual uniqueness, together with the doctrine of external causes of variation, were at the heart of Semon's answer to the challenges of the twentieth century. Entwicklungsmechanik, Semon argued, was misguided as long as it concerned itself exclusively with the inner causes of change. The experimental embryologist reasoned that the fusion of the sperm and egg nuclei determined the outcome of the first cleavage division; that the position of each daughter cell in the early embryo then caused it to divide and differentiate in a certain way; and that the subsequent development of each organ was determined by further differences in the internal environment. But, according to Semon, all those internal causes and effects were at most only half the story; the mnemic constitution of the embryo's protoplasm were just as important.

Here, incidentally, we see Semon lending support to Plate's claim, contra Wasmann, that every individual had a unique constitution and would therefore respond uniquely to an environmental stimulus. The unique constitution was a product of historical events, as "remembered" by the protoplasm. ${ }^{44}$

Since every individual had a unique complement of engrams, Entwicklungsmechanik, and experimental methodology generally, had to beware of treating all individuals as interchangeable. The ubiquity of variation made it unsafe to generalize from biological experiments or to assume that the experimental treatment alone was the cause of the experimental outcome.

This line of reasoning led Semon to his rebuttal of Mendelian genetics as well. The Mendelians, too, failed to ask about the histories of their experimental specimens and viewed them as interchangeable, just because they shared a particular characteristic. For Semon, Mendelian phenomena such as segregation or dominance were merely special cases of developmental plasticity, which he explained as follows: Imagine that you had heard two different versions of a line of Goethe's poetry, which differed only at the end. If the beginning of the line is then read aloud to you as a stimulus, which ending should ekphorize and spring to mind? It might be either one, depending on the history of your experiences with Goethe, and on present circumstances. Similarly, an embryo could have two or more engrams ready to ekphorize at any given point in development, and there was no way to predict which one would it would be in any individual case. Such dichotomies or branching points in development accounted for divergence between the sexes, between castes of bees and ants, and other kinds of variation within a species. ${ }^{45}$

These branching points also allowed Semon to claim his system as a fully

44. Ibid., 229-253.

45. Ibid., 146-147, 221-225 \& 297-259. 
fledged alternative to Mendelian genetics. If one hereditary trait appeared to be "dominant" over another, all that meant, to Semon, was that one of two engrams was consistently ekphorized in the hybrid. If the recessive trait reappeared in the next generation, that was the result of a developmental branching that favored the other engram in some of the offspring. He could even generate the characteristic Mendelian ratios by assigning an equal probability of ekphorization to every engram at a given branching point, just as the Mendelians assigned equal probabilities to the transmission of alleles. Semon argued that one should not accept the Mendelian model of genes located on chromosomes and dictating heredity just because it made the correct quantitative predictions. His memory analogy could match that feat. ${ }^{46}$

\section{Paul Kammerer as a Monist}

Paul Kammerer never met Haeckel and had mixed feelings about Haeckel's biological work, but admired the program for monism and the way Haeckel based it in evolutionary theory. Politically, he was by far the leftmost of the scientists discussed here, and he counted himself a Socialist. Kammerer's Socialist leanings and pacifism contrasted sharply with Haeckel's liberal nationalism and support for the First World War, and he did not shy away from confrontation with other monists, many of whom made biological arguments for nationalism and German racial superiority. ${ }^{47}$ In religion, Kammerer appears not to have been a believer at all, certainly not in any organized religion. He was raised a Catholic, but he had just enough Jewish ancestry to make him a target for the anti-Semites.

Paul Kammerer is not remembered primarily for his monism, but for his efforts to produce experimental demonstrations of the inheritance of acquired characteristics, for accusations of fraud made against him, and for his dramatic suicide in $1926 .{ }^{48}$ But Kammerer's zeal for the inheritance of acquired characteristics was rooted in a conception of Darwinism that was very close to Haeckel's,

46. Ibid., 297-325 \& 333-345.

47. Paul Kammerer, "Nationalismus und Biologie," Das monistische Jahrhundert: Wochenschrift für wissenschaftliche Weltanschauung und Weltgestaltung 2, no. 42 (1914): 1177-1185.

48. Albrecht Hirschmüller, "Paul Kammerer und die Vererbung erworbener Eigenschaften," Medizinhistorisches Journal 26 (1991): 26-77; Sander Gliboff, "The Case of Paul Kammerer: Evolution and Experimentation in the Early Twentieth Century," Journal of the History of Biology 39 (2006): 525-563. For an influential attempt at rehabilitating Kammerer, see Arthur Koestler, The 
in which variation and evolutionary progress were driven by environmental effects. He also shared Haeckel's monistic ideals and the goal of keeping the causes of variation and adaptation mechanistic. Toward this end, however, he took a different tack from Semon's and Plate's, particularly in his embrace of both genetics and experimentalism.

Kammerer aspired to inherit Haeckel's mantle as the leading Germanlanguage popularizer of Darwinism and proselytizer for a materialistic or monistic view of life and a biological basis for ethics and politics. With feigned modesty, Kammerer once described himself as a mere pebble compared to the planet-sized presence and legacy of an Ernst Haeckel, but he added that he was a very special pebble. With the aid of Haeckel's gravitational influence, he felt he could be the one to start a landslide and change the face of the globe. ${ }^{49}$ To that end, Kammerer devoted a great deal of effort to public lectures, adult education, and popular writing, linking specific points of heredity and evolutionary theory to social, political, and religious implications. Kammerer's essays in monist publications made especially strong connections between Haeckel's older program and Kammerer's modernized goals and theories.

Kammerer came out strongly in support of Haeckel's recapitulationism and against ahistorical Entwicklungsmechanik and newer interpretations of embryology. ${ }^{50}$ He elaborated on Haeckel's principle of the unity of mental and material phenomena and the notion of the cell as the fundamental unit of body as well as mind. ${ }^{51}$ And he attacked Weismann for trying to overturn Haeckel's monistic-mechanistic system by denying the heritability of environmental ef-

Case of the Midwife Toad (London: Hutchinson, 1971). And for reassertions of the fraud charges, Lester R. Aronson, "The Case of The Case of the Midwife Toad," Behavior Genetics 5 (1975): 115-125; Gerald Weissmann, "The Midwife Toad and Alma Mahler: Epigenetics or a Matter of Deception?" FASEB Journal 24 (2010): 2591-2595.

49. Paul Kammerer, "Haeckel und ich: Der Planet und der Kieselstein," in Was wir Ernst Haeckel verdanken: Ein Buch der Verehrung und Dankbarkeit, ed. Heinrich Schmidt (Leipzig: Unesma, 1914).

50. Paul Kammerer, "Das biogenetische Grundgesetz," Das monistische Jahrhundert: Wochenschrift für wissenschaftliche Weltanschauung und Weltgestaltung 1/2, no. 22 (1913): 721-727.

51. Paul Kammerer, "Gefühl und Verstand," Monatsblätter des Deutschen Monistenbundes, Ortsgruppe Hamburg, April/May 1914, from a photocopy in the Paul Kammerer Papers, American Philosophical Society, Philadelphia. 
fects. ${ }^{52}$ Kammerer put a modern gloss on Haeckel's doctrines by illustrating them with examples from his own experiments and field studies, applying them to current issues in genetics and eugenics, and arguing that they were the biological theories best compatible with monism and cultural progress.

Two essays from 1912 and 1913, on heredity, illustrate Kammerer's monism particularly well. In "Monistische und dualistische Vererbungslehre" [Monistic and Dualistic Hereditary Theory], ${ }^{53}$ Kammerer applied Haeckel's distinction between the roles of internal and external causes of change. His main targets were Weismann and various Mendelians, whom he accused of denying the importance of the environment in inducing evolutionary change. These essays appealed to monist assumptions about the unity of all substance to show that the Weismannian distinction between germplasm and somatoplasm was counterintuitive, unnatural, and "dualistic," a term that his readers would take to mean not only belief in two biological substances, but also in a non-material spirit world. Kammerer disparaged "the idea that there could be parts in an organism [i.e., like the isolated germplasm] that have nothing to do with the good or ill of the rest," and he compared the germplasm to a parasite:

In the same way that, for example, no attributes of the human form are transferred to the tapeworm just because it lies in the human bowels, just as little of the personal experiences of the individual are conveyed to the germplasm that is nourished by him and is in a certain way parasitic on the germ-bearing body. ${ }^{54}$

Kammerer's main objection to the idea of a separate germplasm was that there was no apparent way for the evolutionary process to produce truly novel, creative changes in it. Echoing Haeckel, and elaborating on his criticism of Weismann, Kammerer complained that the germplasm was completely insulated from environmental effects and indeed from just about any imaginable causes of change. ${ }^{55}$ By Kammerer's reading, the "determinants," the elementary hereditary units in the Weismannian germplasm, could not change at all.

52. Paul Kammerer, "Körperplasma und Keimplasma," Das monistische Jahrhundert: Wochenschrift für wissenschaftliche Weltanschauung und Weltgestaltung 2, no. 29 (1913): 668-677.

53. Paul Kammerer, "Monistische und dualistische Vererbungslehre," Das monistische Jahrhundert: Wochenschrift für wissenschaftliche Weltanschauung und Weltgestaltung 1, pt. 1, no. 7 (July 1, 1912): 225-235.

54. Ibid., 226.

55. This is perhaps unfair, because by the time of Kammerer's writing, Weismann had actually given several different accounts of whether or how 
Variation arose only by means of sexual reproduction, which "continually made new combinations out of a permanently given stock of characteristics." 56

This meant, according to Kammerer, that all heritable characteristics were "contained in the germ from the beginning." Sexual reproduction could bring old determinants together in new combinations, and selection could eliminate some of them, but that was all. There was no provision for anything really new:

Something new can only arise through selection, which can only eradicate the non-useful characteristics and accumulate the useful - as well as through crossing, which continually makes new combinations out of the supply of characteristics that is given once and for all. ${ }^{57}$

For Kammerer, the immortal and unchanging determinants therefore represented a revival of preformationism, in which evolution could only work out the lineage's pre-existing potential, and from preformationism it was but a small step to creationism.

Kammerer included standard interpretations of Mendelism, especially the saltational ones, in the same dualist-preformationist-creationist category as Weismann's germplasm theory. He called them all veiled throwbacks to archaic belief in the fixity of species, "because [they] implied a doctrine of, if not absolute, then relative immutability of plant- and animal species." [Emphasis original]. Such a theory was not only false, but incomplete and intellectually unsatisfying:

The inquisitive mind, searching for causes, will feel most of all unsatisfied because the very first appearance of those myriad traits ("determinants"), of which it is asserted over and over that they were always present in the germ, remains in the dark. ${ }^{58}$

Most of the essay was devoted to freeing Mendelian genetics of Weismannian influences. What the theory needed, according to Kammerer, was a properly

the germplasm could be modified. Kammerer (like Haeckel) seems to have been holding him to the version from: August Weismann, Die Bedeutung der sexuellen Fortpflanzung für die Selections-Theorie (Jena: Gustav Fischer, 1886). On the evolution of Weismann's views on the causes of variation, see Rasmus G. Winther, "August Weismann on Germ-Plasm Variation," Journal of the History of Biology 34 (2001): 517-555.

56. Kammerer, "Monistische und dualistische Vererbungslehre," 225-226.

57. Ibid., 226-227.

58. Ibid., 227, emphasis original. 
scientific and monistic account of genetic change, that is, of the causes of mutations. He accused geneticists of treating mutations as random or spontaneous and uncaused, which was unscientific and unacceptable to a monist:

It is no coincidence that modern geneticists, Mendelians, and mutation theorists are mostly also dualists: vitalists and psychists, who consider life to stand outside the realm of natural causality. The proponents of the monistic theory of heredity, in contrast, are mechanists, energeticists. ${ }^{59}$

Kammerer's solution to the problem of mutation was Haeckel's doctrine of external causes. Even though he could not pinpoint the causes of mutation any better than his opponents, he knew there must be a materialistic and externalistic explanation. The hereditary material must be shaken up somehow, by environmental influences. He cited his own experiments as evidence that the environment could alter an organism's heredity, and he argued that there was no difference, in principle, between the continuous changes he produced in the laboratory and the more discrete changes that are classified as mutations.

Last, but not least, Kammerer argued that the Weismannian view of Mendelism had to be rejected because of its social and political consequences. He made a case for the inheritance of acquired characteristics as the basis for and justification of universal education and public health measures, and contrasted it with the ruthlessness of selectionist eugenics: "The reactionaries in science and politics reach out over the doctrine of the non-heritability of acquired characteristics to shake each other's hands." 60 Indeed, Kammerer spent many years promoting an elaborate program for social, cultural, moral, and medical progress, based on the premise that the beneficial effects of medication, nutrition, education, and practice could be made hereditary, ${ }^{61}$ and these monistic essays show how strongly his social views and plans were rooted in Haeckel's monism and teachings about external causes of change.

\section{Conclusion}

Haeckel's monism might have had its basis in evolutionary theory, but it also fed back upon his interpretation of that theory. In particular, it led him to focus on purposeless, unpredictable, and mechanistic causes of variation and adaptive

59. Ibid., 229.

60. Ibid., 231.

61. Paul Kammerer, Das biologische Zeitalter: Fortschritte der organischen Technik (Vienna: Verein Freie Schule, [1920]). 
change, of which the most important was the inheritance of environmental effects. The same monistic considerations also informed and motivated the later work of Plate, Semon, and Kammerer, who had to find new ways to defend the primacy of environmental causes of variation and the inheritance of environmentally induced characteristics in the early twentieth century. Their particular interpretations of evolution and heredity diverged from each other and from Haeckel's, but they all agreed on the demarcation criteria for telling monistic from vitalistic and teleological theories.

By the time of the modern evolutionary synthesis of the 1930s and 1940s, these old-school Darwinians were no longer held in very high esteem. Haeckel's recapitulation theory had been reduced to a caricature, and his account of the inheritance of acquired characteristics was looked upon as teleological - just the way Wasmann wanted it. Kammerer's career had ended in a scandal that tainted most other research on the inheritance of acquired characteristics by association. Semon's theory of memory was largely forgotten, except perhaps by psychologists, who had little interest in its evolutionary implications. And Plate's last-ditch efforts to save the inheritance of acquired characteristics were treated as historical curiosities. ${ }^{62}$

And yet the line that they had drawn and defended, between mechanistic, external causes of variation and internally generated, vitalistic, and teleological ones, remained more or less intact. The concept of the random genetic mutation, as it developed from the late $1920 \mathrm{~s}$ on, ${ }^{63}$ stayed within the prescribed boundaries, as it traced the ultimate causes of heritable variation to impersonal and purposeless external agencies such as X-rays, cosmic rays, or chemical mutagens. Although they were not necessarily random in the statistical sense, they were unpredictable, unintentional, and unrelated to the needs of the organism. They were therefore well suited to the role once played in Haeckel's monistic system by the inheritance of acquired characteristics and environmental effects, and

62. Harry Federley, "Weshalb lehnt die Genetik die Annahme einer Vererbung erworbener Eigenschaften ab? Weshalb lehnt die Genetik die Annahme einer Vererbung erworbener Eigenschaften ab?" Zeitschrift für induktive Abstammungs- und Vererbungslehre 54 (1930): 20-43; Ludwig Plate, "Warum muß der Vererbungsforscher an der Annahme einer Vererbung erworbener Eigenschaften festhalten? Einige kritische Bemerkungen zu den Tübinger Verhandlungen, besonders zu Federleys Vortrag," Zeitschrift für induktive Abstammungs- und Vererbungslehre 58 (1930): 266-292.

63. Hermann J. Muller, "Artificial Transmutation of the Gene," Science 66 (1927): 84-87. 
they continue to lend support to a view of the natural world as mechanistic, unpredictable, and unguided.

\section{Bibliography}

Aronson, Lester R. "The Case of The Case of the Midwife Toad." Behavior Genetics 5 (1975): 115-125.

Barantzke, Heike. "Erich Wasmann (29.5.1859-27.2.1931): Jesuit und Zoologe in Personalunion." Jahrbuch für Geschichte und Theorie der Biologie 6 (1999): 77-140.

Bowler, Peter J. Review of H. G. Bronn, Ernst Haeckel, and the Origins of German Darwinism, by Sander Gliboff. Isis 100 (2009): 671-672.

Breidbach, Olaf. "The Conceptual Framework of Evolutionary Morphology in the Studies of Ernst Haeckel and Fritz Müller." Theory in Biosciences 124 (2006): 265-280.

_. "The Former Synthesis: Some Remarks on the Typological Background of Haeckel's Ideas About Evolution." Theory in Biosciences 121 (2002): 280-296.

Di Gregorio, Mario A. From Here to Eternity: Ernst Haeckel and Scientific Faith. Göttingen: Vandenhoeck \& Ruprecht, 2005.

Federley, Harry. "Weshalb lehnt die Genetik die Annahme einer Vererbung erworbener Eigenschaften ab? Weshalb lehnt die Genetik die Annahme einer Vererbung erworbener Eigenschaften ab?" Zeitschrift für induktive Abstammungs- und Vererbungslehre 54 (1930): 20-43.

Gliboff, Sander. H. G. Bronn, Ernst Haeckel, and the Origins of German Darwinism: A Study in Translation and Transformation. Cambridge, MA: MIT Press, 2008.

—. "The Case of Paul Kammerer: Evolution and Experimentation in the Early Twentieth Century." Journal of the History of Biology 39 (2006): $525-563$.

Goldschmidt, Richard. Portraits from Memory: Recollections of a Zoologist. Seattle: University of Washington Press, 1956.

Gould, Stephen J. Ontogeny and Phylogeny. Cambridge, MA: Belknap Press of Harvard University Press, 1977. 
Haeckel, Ernst. "Darwin as an Anthropologist." In Darwin and Modern Science: Essays in Commemoration of the Centenary of the Birth of Charles Darwin and of the Fiftieth Anniversary of the Publication of the "Origin of Species," edited by A. C. Seward, 137-151. Cambridge: Cambridge University Press, 1909 .

- Der Kampf um den Entwicklungsgedanken: Drei Vorträge, gehalten am 14., 16. und 19. April 1905 im Saale der Sing-Akademie zu Berlin. Berlin: Georg Reimer, 1905.

. "Die Gastraea-Theorie, die phylogenetische Classification des Thierreichs und die Homologie der Keimblätter." Jenaische Zeitschrift für Naturwissenschaft 8 [= NF 1] (1874): 1-55.

- Die Perigenesis der Plastidule: Oder die Wellenzeugung der Lebenstheilchen: Ein Versuch zur mechanischen Erklärung der elementaren EntwickelungsVorgänge. Berlin: Georg Reimer, 1876.

- Generelle Morphologie der Organismen: Allgemeine Grundzüge der organischen Formen-Wissenschaft, mechanisch begründet durch die von Charles Darwin reformierte Descendenz-Theorie. 2 vols. Berlin: Georg Reimer, 1866.

Last Words on Evolution: A Popular Retrospect and Summary. Trans. Joseph McCabe. London: A. Owen, 1906.

. Natürliche Schöpfungs-Geschichte: Gemeinverständliche wissenschafttiche Vorträge über die Entwicklungslehre im allgemeinen und diejenige von Darwin, Goethe und Lamarck im besonderen. $11^{\text {th }}$ ed. Berlin: Georg Reimer, 1911.

—. "Zur Phylogenie der australischen Fauna: Systematische Einleitung." Introduction to Zoologische Forschungsreisen in Australien und dem malayischen Archipel: Mit Unterstützung des Herrn Dr. Paul von Ritter, ausgeführt in den Jahren 1891-1893, by Richard Semon, 1, pt. 1: I-XXIV. Jena: Gustav Fischer, 1893.

Hirschmüller, Albrecht. "Paul Kammerer und die Vererbung erworbener Eigenschaften." Medizinhistorisches Journal 26 (1991): 26-77.

His, Wilhelm. Unsere Körperform und das physiologische Problem ihrer Entstehung. Leipzig: F. C. W. Vogel, 1874. 
Jaekel, Otto. "Erwiderung auf Herrn Plate's Kritik meines Aufsatzes über Descendenz." Naturwissenschaftliche Wochenschrift 18 [= NF 2] (1902): 234-235.

Kammerer, Paul. "Das biogenetische Grundgesetz." Das monistische Jahrhundert: Wochenschrift für wissenschaftliche Weltanschauung und Weltgestaltung 1/2, no. 22 (1913): 721-727.

- Das biologische Zeitalter: Fortschritte der organischen Technik. Vienna: Verein Freie Schule, [1920].

—_. "Gefühl und Verstand." Monatsblätter des Deutschen Monistenbundes, Ortsgruppe Hamburg, April/May 1914. From a photocopy in the Paul Kammerer Papers, American Philosophical Society, Philadelphia.

_ . "Haeckel und ich: Der Planet und der Kieselstein." In Was wir Ernst Haeckel verdanken: Ein Buch der Verehrung und Dankbarkeit, edited by Heinrich Schmidt, 2: 6-14. Leipzig: Unesma, 1914.

__. "Körperplasma und Keimplasma." Das monistische Jahrhundert: Wochenschrift für wissenschaftliche Weltanschauung und Weltgestaltung 2, no. 29 (1913): 668-677.

_. "Monistische und dualistische Vererbungslehre." Das monistische Jahrhundert: Wochenschrift für wissenschaftliche Weltanschauung und Weltgestaltung 1, pt. 1, no. 7 (July 1, 1912): 225-235.

_. "Nationalismus und Biologie." Das monistische Jahrhundert: Wochenschrift für wissenschaftliche Weltanschauung und Weltgestaltung 2, no. 42 (1914): 1177-1185.

—. "Richard Semon: Zur Wiederkehr seines Todestages." Der Abend (Vienna), December 27, 1920. From a photocopy in the Kammerer Papers, APS Library, Philadelphia.

Koestler, Arthur. The Case of the Midwife Toad. London: Hutchinson, 1971.

Levit, Georgy S. and Uwe Hoßfeld. "The Forgotten 'Old-Darwinian' Synthesis: The Evolutionary Theory of Ludwig H. Plate (1862-1937)." NTM: Internationale Zeitschrift für Geschichte und Ethik der Naturwissenschaften, Technik und Medizin 14 (2006): 9-25.

Lustig, Abigail. "Erich Wasmann, Ernst Haeckel and the Limits of Science." Theory in Biosciences 121 (2002): 252-259. 
Muller, Hermann J. "Artificial Transmutation of the Gene." Science 66 (1927): $84-87$.

Nordenskiöld, Erik. The History of Biology: A Survey. Trans. Leonard Bucknall Eyre. 1928. Reprint, New York: Tudor Publishing, 1936.

Pauly, August. Darwinismus und Lamarckismus: Entwurf einer psychophysischen Teleologie. Munich: Ernst Reinhardt, 1905.

Penzlin, Heinz, editor. Geschichte der Zoologie in Jena nach Haeckel (19091974). Jena and Stuttgart: Gustav Fischer, 1994.

Plate, Ludwig. Die Abstammungslehre: Tatsachen, Theorien, Einwände und Folgerungen in kurzer Darstellung. $2^{\text {nd }}$ ed. Jena: Gustav Fischer, 1925.

_. "Gegen den Psychovitalismus: Nachwort zu dem vorstehenden Aufsatze von O. Prochnow: 'Mein Psychovitalismus.'" Archiv für Rassen- und Gesellschafts-Biologie 6 (1909): 237-239.

_. "Rede des Herrn Prof. Plate." In Ultramontane Weltanschauung und moderne Lebenskunde, Orthodoxie und Monismus: Die Anschauungen des Jesuitenpaters Erich Wasmann und die gegen ihn in Berlin gehaltenen Reden, edited by Ludwig Plate, 52-77. Jena: Gustav Fischer, 1907.

- Selektionsprinzip und Probleme der Artbildung: Ein Handbuch des Darwinismus. $4^{\text {th }}$ ed. Leipzig and Berlin: Wilhelm Engelmann, 1913.

—. Über die Bedeutung des Darwin'schen Selectionsprinzips und Probleme der Artbildung. $2^{\text {nd }}$ ed. Leipzig: Wilhelm Engelmann, 1903.

"Ueber O. Jaekel's Schrift betreffend die verschiedenen Wege phylogenetischer Entwicklung." Naturwissenschaftliche Wochenschrift 18 [= NF 2] (1902): 101-3.

, editor. Ultramontane Weltanschauung und moderne Lebenskunde, Orthodoxie und Monismus: Die Anschauungen des Jesuitenpaters Erich Wasmann und die gegen ihn in Berlin gehaltenen Reden. Jena: Gustav Fischer, 1907.

- Vererbungslehre: Mit besonderer Berücksichtigung des Menschen, für Studierende, Ärzte und Züchter. 2 vols. Jena: Gustav Fischer, 1913.

- Vererbungslehre: Mit besonderer Berücksichtigung der Abstammungslehre und des Menschen. 3 vols. $2^{\text {nd }}$ ed. Jena: Gustav Fischer, 1932-1938. 
. "Warum muß der Vererbungsforscher an der Annahme einer Vererbung erworbener Eigenschaften festhalten? Einige kritische Bemerkungen zu den Tübinger Verhandlungen, besonders zu Federleys Vortrag." Zeitschrift für induktive Abstammungs- und Vererbungslehre 58 (1930): 266-292.

Prochnow, Oskar. "Mein Psychovitalismus." Archiv für Rassen- und GesellschaftsBiologie 6 (1909): 232-236.

Richards, Robert J. "Ernst Haeckel and the Struggles Over Evolution and Religion." Annals of the History and Philosophy of Biology 10 (2005): 89115 .

- The Tragic Sense of Life: Ernst Haeckel and the Struggle Over Evolutionary Thought. Chicago and London: University of Chicago Press, 2008.

Robinson, Gloria. "Plate, Ludwig Hermann." In Dictionary of Scientific Biography, edited by Charles C. Gillispie, sub nomen. New York: Charles Scribner's Sons, 1975.

Russell, E. S. Form and Function: A Contribution to the History of Animal Morphology. London: John Murray, 1916.

Sandmann, Jürgen. Der Bruch mit der humanitären Tradition: Die Biologisierung der Ethik bei Ernst Haeckel und anderen Darwinisten seiner Zeit. Stuttgart and New York: Gustav Fischer, 1990.

Schacter, Daniel L. Stranger Behind the Engram: Theories of Memory and the Psychology of Science. Hillsdale, NJ: Lawrence Erlbaum, 1982.

Schatzmann, Jürg. Richard Semon (1859-1918) und seine Mnemetheorie. Zürich: Juris-Verlag, 1968.

Schmidt, Heinrich. Ernst Haeckel und sein Nachfolger: Professor Dr. Ludwig Plate. Jena: Volksbuchhandlung, 1921.

Semon, Richard. "Aus Haeckels Schule." In Was wir Ernst Haeckel verdanken: Ein Buch der Verehrung und Dankbarkeit, edited by Heinrich Schmidt, 2: 217-222. Leipzig: Unesma, 1914.

—. Die Mneme als erhaltendes Prinzip im Wechsel des organischen Geschehens. Leipzig: Wilhelm Engelmann, 1904.

. Die Mneme als erhaltendes Prinzip im Wechsel des organischen Geschehens. $2^{\text {nd }}$ ed. Leipzig: Wilhelm Engelmann, 1908. 
- Zoologische Forschungsreisen in Australien und dem malayischen Archipel: Mit Unterstützung des Herrn Dr. Paul von Ritter, ausgeführt in den Jahren 1891-1893. 6 vols. Jena: Gustav Fischer, 1893-1913.

Sloan, Phillip R. "Buffon, German Biology, and the Historical Interpretation of Biological Species." British Journal for the History of Science 12 (1979): 109-153.

Uschmann, Georg. "Ernst Haeckel und der Mendelismus." Folia Mendeliana Musei Moraviae Brno 6 (1971): 311-318.

Wasmann, Erich. "Theistische und atheistische Entwicklungslehre: Darwinismus und Entwicklungslehre." II. Vortrag des P. Wasmann, am 14. Februar im Oberlichtsaal der Berliner Philharmonie. In Ultramontane Weltanschauung und moderne Lebenskunde, Orthodoxie und Monismus: Die Anschauungen des Jesuitenpaters Erich Wasmann und die gegen ihn in Berlin gehaltenen Reden, edited by Ludwig Plate, 26-36. Jena: Gustav Fischer, 1907.

Weir, Todd, editor. Monism: Science, Philosophy, Religion, and the History of a Worldview. New York: Palgrave USA, 2012.

Weismann, August. Die Bedeutung der sexuellen Fortpflanzung für die SelectionsTheorie. Jena: Gustav Fischer, 1886.

Weissmann, Gerald. "The Midwife Toad and Alma Mahler: Epigenetics or a Matter of Deception?" FASEB Journal 24 (2010): 2591-2595.

Winther, Rasmus G. "August Weismann on Germ-Plasm Variation." Journal of the History of Biology 34 (2001): 517-555. 